Article

\title{
Understanding the Hiring Issues of the Craft Workers in the UAE's Construction Labor Market: Project Managers Perspective
}

\author{
Mohammed Albattah*(D, Amna Shibeika and Muhammad Sami Ur Rehman (D)
}

check for

updates

Citation: Albattah, M.; Shibeika, A.; Sami Ur Rehman, M. Understanding the Hiring Issues of the Craft Workers in the UAE's Construction Labor Market: Project Managers Perspective. Buildings 2022, 12, 26. https://doi.org/10.3390/ buildings12010026

Academic Editors: Agnieszka Leśniak, Krzysztof Zima and Audrius Banaitis

Received: 3 November 2021 Accepted: 28 December 2021 Published: 31 December 2021

Publisher's Note: MDPI stays neutral with regard to jurisdictional claims in published maps and institutional affiliations.

Copyright: (c) 2021 by the authors. Licensee MDPI, Basel, Switzerland. This article is an open access article distributed under the terms and conditions of the Creative Commons Attribution (CC BY) license (https:// creativecommons.org/licenses/by/ $4.0 /)$.
Department of Architectural Engineering, College of Engineering, United Arab Emirates University, Al Ain 15551, Abu Dhabi, United Arab Emirates; a.shibeika@uaeu.ac.ae (A.S.); 202090209@uaeu.ac.ae (M.S.)

* Correspondence: mohammed.battah@uaeu.ac.ae

\begin{abstract}
The construction industry in the United Arab Emirates (UAE) is faced with negative project performance, including low productivity, higher costs, delays in project completion, and defects during construction. One of the main reasons for these issues is the engagement of unskilled craft workers. Despite these labor issues, demand for construction projects in the UAE has been explosively increasing, in part due to Dubai winning the hosting of Expo 2020, which has given rise to an unprecedented demand for skilled construction craft workers. This study aimed to investigate the views and experiences of construction project managers regarding the reasons and challenges associated with the hiring of skilled craft workers in the construction labor market of the UAE. To fulfill the study purpose, the authors conducted structured open-ended interviews with UAE construction project managers. The results revealed several reasons for hiring craft workers despite a clear lack of qualifications and suggest some potential solutions.
\end{abstract}

Keywords: craft workers; skilled workforce; UAE; construction labor market; construction projects; hiring; skills; construction productivity

\section{Introduction}

It is widely understood that construction infrastructure investment in transportation, energy, commercial and residential projects, among other sectors of the economy, can induce large, beneficial, economic multiplier and spillover effects [1]. Given such large potentially powerful, positive investment leverage, the details of how the United Arab Emirates (UAE) construction industry projects are organized and executed are critical to the wellbeing of UAE citizens and international visitors [2]. Dubai, which is one of the seven Emirates of the $\mathrm{UAE}$, has become one of the most rapidly growing cities in the world $[3,4]$. The construction industry - the largest employment sector in the UAE-employs $20 \%$ of the approximately six-million-person workforce in the UAE or 1.2 million construction workers [5]. Together, these workers earn approximately $12.3 \%$ of the total UAE workforce revenue, 50.3 billion dirhams or $\$ 13.6$ billion U.S. dollars - the third-highest revenue of all UAE employment sectors ahead of government services, retail trade, and reparation categories, making up $14 \%$ of the UAE GDP [6,7]. There was a peak demand for construction workers to assemble 3200 projects in the Dubai area, building infrastructure projects worth $\$ 245$ billion U.S. dollars, heightened by the need to build the facilities required for Expo 2020 [8,9]. The demand is going to inflate in the coming years due to the recent initiative of the UAE government, termed as 'Projects of the 50', which aims at spending 5 billion dirhams in the next five years to support various development projects alongside the influx of investment in the private sector [10].

Ren et al. found, in a 2008 survey of Dubai construction establishments, that there was a clear pattern of non-participation of UAE citizens in the UAE construction industry as well as key positions in the UAE government [3]. Virtually all-99\%—of the low-skilled 
labor jobs in Dubai in 2008 were taken by foreign employees [3,4]. There were almost no UAE citizens working as craft workers [11]. Additionally, the overwhelming majority$89 \%$ - of construction managers in Dubai, UAE, where most of the country's construction was taking place, were foreign citizens [5]. More than three-quarters of the foreign workers in the UAE-77\% - were formerly blue-collar craft workers, and the balance was trade and service workers [3]. As a point of reference, approximately one third of all residents in the UAE-3.38 million people-live in the city of Dubai, the most populous city in the UAE and the capital of the Emirate of Dubai [12].

Delays can easily happen with a mixed cultural workforce from many different countries. In the UAE, and particularly in Dubai, there is a mixed nationality workforce that has brought a wide variety of cultural, religious, and educational backgrounds and traditions to the work sites, confirming other studies of craft workers found in the same region $[13,14]$. This could be challenging to construction project managers intent on meeting project deadlines. For instance, Muslim electricians would not show up to work on holy Friday, Christian plumbers would miss work on Sundays, or Indian painters would be absent from work because of what seemed like randomly selected holiday festivals [3]. The unique negative impact of such a disparate multi-national workforce on efficient construction scheduling and productivity could be significant depending upon the specifics of the project [3]. These circumstances are exacerbated by the fact that nearly $90 \%$ of the construction labor workforce consists of non-UAE foreign nationals made up of 202 nationalities, much as they were in 2010 [5,15]. Even the number of Indian, Bangladeshi, and Pakistani expatriates working in the UAE was greater than the entire UAE population [12,16]. One analyst suggested that job security in many other cultures and nations could have been the primary issue motivating the existence of the labor market in the UAE at the time [14]. The ongoing wave of COVID-19 has also prompted the local construction industry to swiftly adopt various technological solutions to complete their projects within the stipulated times [17]. Moreover, the shift towards an emerging concept of Industry 4.0 and Construction 4.0 has also prompted a series of innovations regarding construction workers, now being conceived as Workers 4.0 [18]. This situation could call for further research and raises an important question, namely, what is the current state of craft workforce development, of current practices, prevailing issues, and potential solutions in the context of the UAE construction industry?

This study aims to explore the process for hiring craft workers in the construction industry in the UAE. This aim was achieved through a structured interview developed and conducted in 2019 to capture views and experiences from construction project managers who were in charge of completed and ongoing construction projects in the Dubai metropolis. The paper is organized as follows. A literature review to understand relevant reasons for the shortage of skilled labor and why unskilled labor is often hired in construction sites in general and specifically in Dubai is presented in the following section. The research methodology and the methods adopted for data collection and analysis are then presented, followed by the findings from the qualitative data analysis for the structured interviews with project managers in Dubai. The paper then concludes with a discussion of the findings, as well as providing recommendations for optimizing hiring skilled craft workers for the booming UAE construction industry.

\section{Background}

A variety of specialized craft, highly skilled, and professional manufacturing services engage in and complete many erections and undertake dismantlement, restorations, and upkeep of the manmade engineering infrastructure and carry out building projects [19]. Clarifying the terminology, many of the jobs in these job categories are completed by a variety of people in occupations who typically specialize, for example, in just restoration, dismantlement, or infrastructure [20]. In the vast majority of locations, the construction industry usually comprises the construction of roads, highways, water supply, sewage treatment plants, and bridges; industrial construction of oil and gas platforms and min- 
ing infrastructure; commercial and residential construction of single-family dwellings, office buildings, and condominium developments [21]. Many services are provided by occupational specialists who are educated, experienced, and occupationally certified in architectural design, construction management, carpentry, civil engineering, electrical engineering, electrician services, general labor, mechanical engineering, plumbing, and steel fixing [19]. Clarifying the construction terminology, occupations are generally a particular kind of work associated with one of these services [20].

According to the International Standard Classification of Occupations (ISCO), a job is defined as "a set of tasks and duties performed or meant to be performed, by one person, including for an employer or in self-employment" [22]. As documented, occupation refers to the kind of work performed in a job. The concept of occupation is defined as a "set of jobs whose main tasks and duties are characterized by a high degree of similarity". A person may be associated with an occupation through the main job currently held, a second job, a future job, or a job previously held [20].

Given the potential for confusion about the key terms used to refer to construction crafts, jobs, knowledge, machinery, materials, occupations, products, projects, services, skills, specializations, and tools, a framework has been recommended to simplify commonly used terms by the International Standard Classification of Education [23]. A framework was put forth consisting of four skill specialization categories: (a) domain of know-how, (b) hand tools and equipment, (c) supplies, stocks, and work materials, and (d) finished products and assistance delivered [24].

It has also been recommended that workers be grouped into three classes based on their recognized skills and training levels in a craft: (a) extensive training, (b) minimal training, and (c) no training/guidance only [20]. Vereen, in her study, clarified the meaning of high and low levels of skills by asserting that highly skilled occupations, such as carpentry, electrification, and pipefitting, are those requiring specialized education or training that can take years to complete [25]. In contrast, she suggested that the general assistance provided by day laborers who work on roofing projects requires no training, little direction, and constant supervision. However, some studies revealed that workers are automatically considered unskilled when they came from less-developed countries [26-28]. Furthermore, workers' characteristics, such as gender and race, are also considered as indicators for their skill level and job performance. Therefore, worker skills can be rendered meaningless, like race or cultural background, in terms of an emigrant's actual capabilities in a host nation [29].

One of the studies defined nine parameters to distinguish between skilled and unskilled workers in the construction industry [30]. These parameters are knowing and executing the safety regulations in the workplace and complying with building codes, knowing and following the labor laws of the land; moreover, knowing the construction material-related issues, construction equipment, and tools-related issues. The study also addressed the personal development-related factors, i.e., professional training on related work, a minimum of two years' work experience, a minimum of primary education, and good physical condition. The authors conducted a questionnaire survey on 71 construction workers in Bangladesh to measure their skill level. In terms of workers' knowledge, the authors found that only $19.35 \%$ of the workers knew and practiced construction safety. In terms of the knowledge of building codes and labors laws, only $2.3 \%$ and $4.87 \%$ of the workers had relevant information respectively. Furthermore, only $6.45 \%$ of the workers knew the construction materials issues and $9.68 \%$ of the workers knew about construction equipment and tools issues. In terms of workers' background and qualifications, the authors found that only $6.45 \%$ of the workers had professional training, $62.5 \%$ had minimal working experience, and $46.06 \%$ of the workers had minimal education. However, $62.25 \%$ of the workers were found to be in good physical condition. The authors believe that the awareness of the building codes is the key driver to enhance the skill level of the workers. 


\subsection{Poor Productivity and Unskilled Workers}

Another study asserted that the construction industry is a labor-intensive industry [31]. To this point, numerous authors have asserted that profitability rests solely on the shoulders of the productivity of this labor [32-34]. Unskilled labor is one of the major causes of construction defects in the building sector and site accidents [35,36]. Associated with this has been poor productivity that can lead to construction delays and cost overruns $[30,33,34,37-40]$. This fact is also observed in the UAE's construction industry [41-43].

On the other hand, a study defined 32 barriers to achieving high construction productivity in Singapore [44]. The authors conducted two methods for collecting the data. First, a questionnaire survey on 109 participants from several companies under the Singapore Contractors Association and the Singapore Chinese Chamber of Commerce and Industry. Second, in-depth interviews with 12 expert participants from both local and foreign companies. The authors found that the second-highest barrier is the poor skills of the workers due to a lack of proper training and experience.

Another study aimed to determine the association between job characteristics and performance at the task level among unskilled craft workers using the burnout theory [44]. The study was conducted in a laboratory environment, in the US, on 22 participants from trainees in a pre-apprenticeship construction education program and from university students in a construction management department. One of their main findings was that unskilled craft workers will not achieve both productivity and safety at equally high levels. Therefore, the task's demands and personal resources need to be planned (i.e., continuous training programs are required) to meet the optimal levels of productivity and safety performance goals.

In addition, the authors identified 73 critical factors that impact labor performance in construction projects in Sri Lanka [38]. The authors conducted a questionnaire survey of 217 contractors. These critical factors were categorized into six categories, which are project-related, labor-related, management/organization-related, technology-related, materials and tools-related, and environment-related. Among these categories, labor and management/organization-related factors were the highest impact categories. However, skill shortage, lack of thinking abilities, and lack of knowledge of construction were the top three critical factors in the labor-related category and were among the top $10 \mathrm{critical}$ factors overall.

\subsection{Shortage of Skilled Workers}

The Australian Business Characteristics Survey of 2011-2012, an annual mail-out survey conducted by the Australian Bureau of Statistics (ABS) defined skills shortage as "an insufficient supply of appropriately qualified workers available or willing to work under existing market conditions" [45]. The most crucial problem for the construction industry is the shortage of skilled workers [46]. It is one of the significant causes of accidents on construction sites that in turn affects construction quality and productivity $[30,35,38,47]$.

Higher-skilled occupations in construction are experiencing greater shortages in comparison to lower-skilled occupations $[37,46]$. The reasons for the skill shortages have been explained by authors and discussed as follows; they are mainly relevant to job conditions, external, and individual factors [46].

I. Job Condition Factors:

- Poor working conditions;

- The geographic location of the job is inconvenient;

- Lack of job security;

- $\quad$ Poor safety.

II. External Factors:

- Energy revolution (increasing oil and gas facilities);

- Economic recovery (the impact of the expansion); 
- $\quad$ Aging of the workforce/retirement;

- Lack of industrial relations and immigration on skill development;

- Poor market information.

III. Individual Factors:

- Poor education/poor training;

- Poor wages;

- Changing skill requirements (make it harder);

- Poor industry image;

- Poor treatment;

- Lack of worker-oriented career path;

- Interested in a college degree (pushed by parents);

- Growth of green jobs (require unique skills).

One of the studies found that there has been a high demand for skilled labor and professionals in the UAE labor market [3]. In addition, many companies suffer from the high turnover and shortages of skilled technicians, engineers, and labor workers, and their impact is quite severe during peak construction periods. These challenges are starting to place immense pressure on construction companies trying to not only compete with counterparts within their sectors but also to maintain safety at construction sites.

The National Industry Advisory Body identified a diverse range of factors contributing to current and future skill shortages [48]. These factors included: an aging workforce and forthcoming retirement rates, changing skills required from various occupations, differences in supply and/or demand of skilled workers as a result of employment arrangements, poor educational qualifications translating into smaller and lower numbers of successful job applicants, and inadequate apprenticeship rates and difficulties in attracting and retaining employees [48].

\subsection{Hiring Unskilled Craft Workers in the UAE Labour Market}

One of the studies mentioned in their study that there are three ways that firms go about hiring workers to meet their demands [49]. (1) Hiring qualified and skilled workers who meet the job requirements takes a long time and much effort. (2) Hiring experienced and skilled workers who do not meet all the job requirements but meet some of them will potentially lead to a mismatch between the job requirements and the workers' skills; therefore, training is needed so the workers acquire the required skills. (3) Hiring young and/or unskilled workers, and providing them with training, internally or externally, to meet the job requirements takes time and effort but costs less than the other two ways. It is more difficult and more expensive to hire qualified, skilled workers from the external labor market [49]. Therefore, firms can reduce external hiring costs, especially in cases where a high number of workers are needed for a short period (i.e., construction firms), by providing internal training for unskilled workers and then retaining them after they finish training [49-51].

The construction boom in Dubai, UAE has led to intense competition for contractors in the city to win construction contracts [8]. In this context, the pressure to underbid other competitive bidding contractors has led to reductions of wages, training, and promotion track job security benefits that in turn has forced contractors to hire unskilled, foreign, migrant, multicultural craft workers to be able to win contracts [52]. A study releveled that low wages are a major reason for the construction industry losing skilled craft workers [53]. This strategy presents a conundrum, however, because completing these contracts in many situations requires highly skilled craftsmen to be able to fulfill the contracts technically and competently. While market forces of supply and demand in such a competitive situation would normally drive offer prices up for skilled craftsmen, shortsighted and/or undercapitalized contractors have been unwilling or unable to take this action [3].

Migrant, non-citizen, multicultural workers make up the overwhelming majority$80 \%$ - of the entire UAE population and an even greater majority— $90 \%$ - of the Dubai population [5,12]. Very few ever qualify and are selected as UAE citizens as it is the policy 
of the UAE government to significantly restrict the citizenship of most foreigners [19]. This is as true of all the technical workers in the construction industry-architects, engineers, surveyors, demolition specialists, water carriers, and cleaners-as it is for all other industrial workers in the UAE. All the craft workers in the construction industry in the UAE are noncitizens because the citizens are not interested in undertaking construction jobs [54]. Noncitizen workers are willing to work under harsh conditions, as obtain in the construction industry, and this is one of the reasons for having unskilled workers in the industry [55].

This section has highlighted the importance of skilled craft workers to achieve efficient productivity throughout the course of a construction project and meet the required deadlines. However, many construction industries around the world are witnessing a shortage of skilled workers and face many serious consequences, e.g., poor productivity, safetyrelated incidents, unwanted delays, increased costs, etc. [37,48,51,52]. The availability of research in the context of Singapore also revealed that hiring unskilled workers has posed a serious problem for the industry [56]. Like Singapore, the UAE's construction industry also hires most foreign workers to meet the demand and from a similar South Asian demographic. Moreover, research studies regarding Sri Lanka and Bangladesh have also identified the heightened proportion of their workforce that is unskilled and stated various factors [30,38]. As the industry in the UAE has also relied for most of its workforce on South Asian nations, this problem seems inherent and calls for further research. The UAE is a progressive country and with the announcement of 'Project of 50', which is a roadmap for the next 50 years for the nation, it is going to adopt technological innovations in every walk of life, including construction, the third-biggest contributor to the country's GDP [10]. Therefore, it is necessary to investigate the issues regarding the unskilled craft workforce.

\section{Materials and Methods}

A database search was conducted to retrieve relevant literature using Scopus and Web of Science online databases. Pre-defined keywords and semantic search strings were used to search for relevant literature. Another restriction was applied to the search regarding the article type and limited only to articles from journals, conference proceedings, and book chapters for high-quality and reliable articles. Moreover, the language of the searched articles was limited to English only. However, the period of publication was not limited to any specific range.

The purpose of this research has been to investigate the current state of craft workforce development in the UAE construction industry. A qualitative exploratory case study approach was adopted to investigate the views and experiences of construction project managers. Due to the undefined issue and novelty of this research in the context of the UAE, the exploratory research design was devised to define the problem that can be the focus of future research studies, in conformance with the grounded theory approach or interpretive research design [56]. It aims at unearthing the reasons and challenges associated with the hiring of skilled craft workers in the construction labor market of the UAE [57]. Project managers' perspectives are important because they directly oversee the substandard nature of the craft workers' performance daily yet they still hire them. The data presented here is based on 15 structured open-ended interviews conducted with project managers who have been engaged in the delivery of current construction projects in the UAE.

The interview comprised three main sections:

1. Section 1 contained personal information about the interviewees in terms of their gender, education, current role, years of experience, and the type of jobs with which they were engaged.

2. Section 2 was focused on exploring the current state of hiring craft workers in the UAE to identify workers' trades, common nationalities, wages, and qualifications.

3. Section 3 addressed the project managers' perspectives on the reasons and challenges associated with hiring the workers through open-ended questions.

The interviews were conducted during summer 2019, and each interview lasted 30-60 min. Suitable project managers were identified through a snowballing process, for 
which the participants referred the researcher to others who might be able to potentially contribute or participate in the study [58]. This method helped in finding and recruiting participants, for example, busy project managers who may otherwise be hard to reach. All the interviewees were male project managers. While they mostly held bachelor's and master's degrees, one project manager had a Ph.D., and another held a high school certificate. Nine of the interviewed project managers had more than 10 years of experience in the construction sector in the UAE, three had less than four years of experience, and three project managers had 4-10 years of experience. All the study participants worked on a range of residential, commercial, industrial, and infrastructure projects. Table 1 summarizes the interviews.

Table 1. Interviewees' level of education and years of experience.

\begin{tabular}{ccc}
\hline & Highest Level of Education & Years of Experience (PM) \\
\hline Interviewee 1 & Master & +10 years \\
Interviewee 2 & Master & $4-10$ years \\
Interviewee 3 & BSc & $1-4$ years \\
Interviewee 4 & Master & $1-4$ years \\
Interviewee 5 & Master & +10 years \\
Interviewee 6 & BSc & +10 years \\
Interviewee 7 & High School & $1-4$ years \\
Interviewee 8 & Other & +10 years \\
Interviewee 9 & Oher & +10 years \\
Interviewee 10 & Master & +10 years \\
Interviewee 11 & Ph.D. & +10 years \\
Interviewee 12 & BSc & $4-10$ years \\
Interviewee 13 & BSc & +10 years \\
Interviewee 14 & BSc & +10 years \\
Interviewee 15 & Master & $4-10$ years \\
\hline
\end{tabular}

Thematic data analysis was adopted for the qualitative data, which was mainly drawn from sections two and three of the interviews [59]. Interview transcripts were produced by the researchers based on the extensive notes taken during the interviews. These transcripts were then organized into themes and sub-themes to address the research questions. The thematic analysis process primarily involves familiarization with the data through reading and re-reading the transcript several times, theme building guided by the literature, and theme definition [60].

To ensure the reliability of the research, the interview protocol was carefully developed considering the relevant literature, and codes and themes were corroborated by the researchers to ensure the validity of the findings [59-63]. However, the analysis presented in this paper has limitations; it is only based on interviews with project managers. Future research could extend the interviews to construction workers, and other data collection methods, such as observation, might be useful to capture site work practices.

The following section will present a descriptive analysis of the status of the labor issues in the UAE based on the interviews. This will be followed by a presentation of the results that focused on the issues of hiring these craft workers.

\section{Results and Discussion}

\subsection{Current State on Craft Workers in UAE}

All 15 project manager participants agreed that the majority of the craft workers in the UAE came from India, Pakistan, and Bangladesh, while the rest came from Egypt, the Philippines, and other nations. The average monthly salary for unskilled craft workers is 600-900 AED and 900-2000 AED for skilled craft workers. In addition to these salaries, employers are required to provide the workers with a place to live, transportation to the job site, health insurance, meals, and flight tickets. 
The participants were asked about the trades that they have difficulty finding skilled/ qualified workers for in their current project. The authors listed several trades and asked the participants to choose from those. Some of the participants had no difficulty finding skilled workers at all, some of them chose one trade only, and the rest chose several different trades. The top-ranked groups for which it was most difficult to hire skilled workers were carpenters, electricians, construction equipment operators, ironworkers, steel fixers, pipe layers, plumbers, pipefitters, and steamfitters. These are considered high-skilled trades based on several construction-related studies which examined difficulties in finding skilled/qualified workers, not just in the UAE, but across many other countries [25,38,39]. Other groups, on the other hand, for which there is no difficulty at all in finding workers or who represent what are ranked as low-skilled trades are painters, maintenance, laborers, and helpers.

\subsection{Why Do UAE Construction Projects Hire Unskilled Craft Workers?}

Analysis of the interviews' data revealed two main issues associated with hiring craft workers in UAE projects: (1) the requirement to employ unskilled workers to do jobs that do not require specific skills, and how this affects project performance in terms of cost and time; and (2) the practical reality of employing unskilled workers to do the jobs of skilled workers because of the difficulty of hiring the latter, this difficulty mainly being caused by cost and time pressures. This is summarized in Table 2.

Table 2. Issues and associated challenges in hiring unskilled craft workers.

\begin{tabular}{ll}
\hline \multicolumn{2}{c}{ Hiring Unskilled Construction Workforce in the UAE } \\
\hline Issues & Associated Challenges \\
\hline $\begin{array}{l}\text { - Unskilled workers are cheaper than } \\
\text { skilled workers }\end{array}$ & $\begin{array}{l}\text { - Negative effect on project performance because of } \\
\text { delays and damages caused by the lack of knowledge } \\
\text { and experience of unskilled workers }\end{array}$ \\
$\begin{array}{l}\text { - High demand for construction } \\
\text { workers due to the fast-growing } \\
\text { construction industry }\end{array}$ & $\begin{array}{l}\text { - Unscrupulous practices by staff recruiting } \\
\text { companies, promoting unskilled workers as skilled } \\
\text { and demanding kickbacks }\end{array}$ \\
$\begin{array}{l}\text { - Almost all the construction workers } \\
\text { are ex-pats }\end{array}$ & $\begin{array}{l}\text { - The need to keep the workers always working, } \\
\text { otherwise they must go home }\end{array}$ \\
\hline
\end{tabular}

The data also revealed insights concerning the consideration of specialized certificates as a factor in hiring craft workers, as well as suggestions for optimizing the hiring of skilled workers. These will be presented in the following sections.

\subsubsection{The Need for and Effect of Hiring Unskilled Workers}

Construction work requires different sets of skills to fulfill different types of craft and trade work. According to the interviewees, one of the main reasons for hiring unskilled workers is that unskilled craft workers can work between jobs easily in low-skilled trade jobs and some types of tasks require unskilled workers. One of the interviewees highlighted that: "Unskilled labor is required to help skilled labor". Another project manager confirmed this when he said the following: "In the project, we need both the unskilled (helpers) and the skilled workers, (because) without one of them the project will have ... difficulties". This confirms from a project manager's perspective that a balance between skilled and unskilled workers is usually needed in construction projects. This is especially important from a cost perspective as highlighted by one project manager as follows: "if you have hundreds of workers then the difference in salaries will have an impact on the revenues of the project or the organization". Therefore, while unskilled labor is needed to do specific low-key jobs, balancing between skilled and unskilled labor is also important for project costs especially for the larger construction projects. 
However, the literature also shows that in comparison to skilled workers, unskilled workers may cause delays and defects in the construction processes. Usually, unskilled craft workers do not have the experience to deal with the materials, so they may damage or destroy these materials [35]. In addition, they do not know the full scope of the work, so they may be unaware that some of their actions may affect future work. Moreover, they do not have the required quality expertise and need more time to learn, so they cannot fulfill all the project requirements by themselves. Although some of the workers understand some of the processes in construction work, overall, they do not yet have a sense of the right and wrong ways of doing things. Furthermore, communication challenges presented by language barriers and minimal education keep many from learning any new skills. These findings resonate with the parameters identified to distinguish between the skilled and unskilled workers in the construction industry, as well as the findings of $[3,30,34]$.

\subsubsection{The Difficulty of Hiring Skilled Workers in the UAE}

Besides the fact that skilled labor is expensive, or as one of the interviewees put it "the qualified guys are expensive", the literature shows that it is difficult to hire skilled workers to work on construction projects for two main reasons: (1) project pressures that require hiring trade workers as quickly as possible at the start of the project (this finding has been shown over the past studies); and (2) the dishonesty of recruitment agencies who often promote unskilled workers as skilled workers [34,52].

The interviews with project managers have revealed that it is very difficult to find skilled craft workers in the UAE labor market because of project cost pressures, time pressures, and the resultant tight deadlines. This is explained by a project manager in the following quote: "Most Dubai contractors ask their subcontractors to hire people with training and trade skills. When projects end, contractors will not keep them because they cannot afford to support these tradespeople during downtimes between jobs. If contractors win competitive contracts which have deadlines that simply cannot be met, they subcontract their work to other subcontractors who have labor that can fulfill the demand. Quality usually suffers when these kinds of demands are made by clients". Due to residency constraints unique to countries such as the UAE where almost all the craftworkers are ex-pats, this means that as soon as the project ends, recruiters will move the workforce to another project. As a result, whenever a new project is starting, it is a challenge to find labor based on the specific requirements for the project. Another reason is also typical in Dubai because of the nature of its rapidly growing construction industry which often leads to extremely tight deadlines and therefore to a greater supply of unskilled workers by hiring agencies to fill the gaps and meet contractors' demands, is expressed by one of the project managers as follows: "When the demands increase for the labor supply agencies, the quality becomes poor". Often this practice results in hiring the unskilled as skilled workers, which means they end up at construction sites where they cannot perform what they were recruited for, so they become helpers or are sent home due to lack of income.

In addition, the construction boom in the UAE has attracted so many job applicants that some might say it has also led to unscrupulous practices by staff recruiting companies, some of whom demand exorbitant kickbacks of up to $50 \%$ of the projected wages.

\subsection{The Consideration of Specialized Certificates as a Factor in Hiring Craft Workers}

Study participants have indicated that some construction companies require specialized certificates testifying to a potential tradesperson's skill level. The said certificates can be a misleading indicator of both theoretical knowledge and practical know-how which can only be gained through experience. One of the participants said: "I have seen several workers with specialized certificates, but they are not performing very well at their job. We as project managers know that many institutions do the training for the craft workers in a rush way and issue the certificates within weeks". Consequently, certificates issued under these kinds of circumstances are nearly valueless. Another participant reasoned that earning the specialized certificate contributed an intangible value to the craftsperson, in that "...the person will be open-minded and able to learn faster". On the other hand, a different project manager 
clarified that not all certificate-granting agencies' certificates are created equal saying: "The quality of the certificate depends on the institute that issues them. For example, the Industrial Training Institute, in India, provides full-time coursework for two years, in each trade, then the craft worker will have the certificate if he passes the exam. Another institute is the Scientific and Technical Center for Building, in the UK. They are so good at what they do that we wouldn't consider certificates from any other unauthorized agency". Thus, construction companies appear to have mixed interpretations of the various specialized certificates they receive from construction craftsperson applicants in that certificates from some authorized agencies are more credible and reliable than others related to work quality and job site safety.

Most construction companies send representatives to meet with, interview, and screen, then vet, verify, test, and validate the specialized certificates held by prospective employees before recruiting these workers. This is an important process because with so much demand for skilled workers and so little supply available it is important to find a prospective worker who will comply with the requirements and be able to fulfill expectations. In case a prospective employee does not make it through the vetting process, they will be passed over. However, the prospect might make it through the vetting process to become a construction employee and later be found not able to do the job that has been assigned. In this case, the employer might have two options: (1) the employee may be given a choice to become a skilled worker under supervision with highly restricted responsibilities and be paid a general laborer's wages, or (2) the employee will be released and sent back to his or her home country. Employees who are critical to construction operation leadership, such as the foreman and the general foreman, are held to a higher standard of vetting, including a specialized certificate required for foremen, documentation of the experience as foremen, recommendations, and testimonials from former employers, and extensive interviews.

Several construction organizations go through the effort and expense of training their employees to do the work expected of them, irrespective of their having specialized certificates. One of the interviewed project managers who had experience with this type of training asserted, "Despite our employees having prior training and specialized certificates, we train them in-house or by sending them to commercial training services as our needs require". Another interviewee added, "We train all of our employees regardless of skill level at our facility at Jabel Ali". However, another project manager had a differing view representing the more expensive concerns of some of the construction companies when he asserted, "Training costs reduce our profit margins and training time limits worker productivity". This evidence shows that while training is important, and some companies provide it, the cost of training the workers and the time spent on that training are important factors to be considered when hiring unskilled works for projects in the UAE.

\subsection{Solutions to Optimize Hiring Unskilled Craft Workers in UAE Construction Projects}

In response to questions about suggestions and solutions to optimize hiring unskilled workers in UAE construction projects the interviewed project managers agreed that the solution should come from both the government and the contractors themselves.

Solutions suggested by the project managers for the government are focused on initiating legislation and practices to improve hiring and retaining both the skilled and unskilled workforce. First, introduce laws to control the quality of workers supplied by third-party agencies in the market. Today these agencies have become risk-free and easy money-making businesses. Therefore, strict control on labor supply agencies is mandatory. One of the participants suggested that the government be encouraged to require by law that each company put at least one skilled and certified worker at each task so that other workers will learn from him/her. In addition, that the government could force the large construction companies by law to provide a vocational program to train their workers and small company sub-contracted workers has also been identified as a key recommendation by a recent research study to improve the performance and productivity of laborers [38]. Second, create a division in the government to control the quality of the workers and their work, similar to what the government has done in controlling worker safety at the job site. 
Third, take some actions to increase the salaries and benefits for workers in government projects, then the private sector will follow suit. This was also suggested by a recent study in the context of Singapore's construction industry, which is very similar to construction in the UAE regarding the hiring of foreign workers to meet the needs [56]. These actions could include increasing the budget of the construction project to allow higher salaries to be paid to qualified and skilled workers, changing the contractor selection criteria to best value instead of the lowest bid, and providing contractors with more time to find skilled workers in the labor market. Finally, educational sessions could be provided for the contractors. These sessions can train them to make calculations of the costs of the reworking defects caused by unskilled workers, illustrating that hiring skilled workers can save time and money. Providing this education could increase the organization's market value by enabling a better reputation to be built in delivering projects on time and within satisfactory quality levels.

Furthermore, the solutions suggested to be adopted by the contractors include the following. First, contractors should aim to employ their workers, instead of sourcing temporary workers from a third-party broker, to save money and ensure the best quality. Second, establish production rate standards to achieve the requirements of a successful project, similar to the suggestion for incorporating tender evaluations in terms of labor productivity and initiating a trend of awarding productivity premiums based on certain productivity targets [56]. If the unskilled worker does not meet this rate, or does the task poorly, then replacing that worker with a skilled worker is recommended for the project and to enhance the contractors' reputations. Third, demonstrate through case studies and lessons learned to project managers that skilled workers can produce high quality, safe, and cost-effective work that in turn can lead to time and cost-efficient construction projects, this to encourage both hiring skilled workers and training unskilled workers too. Fourth, linked to the previous suggestion, encourage the creation of a vocational program school at the company level, and provide both theoretical and practical formal training for their workers. A recent Construction Labor Productivity (CLP) framework also highlighted the importance and need for similar training and an evaluation program [44]. This could help to continuously train the existing and new workers to improve overall work quality. One of the project managers said, "We as a construction company must understand that it makes a huge difference when we train our workers to fulfill company standards and requirements. It gives them a better understanding about their work productivity, safety, planning, and progress". Fifth, create clear expectations and worker evaluation methods before hiring. Finally, establish clear policies and requirements for recruiting the type and skill level of workers for each project, in line with the recommendations provided by a recent study in the context of the Sri Lankan construction industry [38]. As one interviewee mentioned, "We have to develop a plan that requires resources to add policies in recruiting workers to avoid unskilled workers".

The above suggestions are mainly focused on regulating the hiring and traininginitial and continuous - of skilled workers, to optimize project delivery in terms of time, cost, and performance. Moreover, many of the suggested solutions were also considered in previous studies conducted in different contexts [4-7].

\section{Conclusions and Recommendations}

The purpose of this study was to explore issues associated with hiring craft workers, the effect of specialized certificates on the hiring of craft workers, and some solutions to overcome the unskilled craft worker issue given by construction project managers. The study was organized to collect and analyze opinions using structured, open-ended interviews with 15 seasoned construction project managers from the UAE. The most valuable contribution of this study was the discovery that the shortage of skilled workers in a context of high demand and stringent requirements to meet deadlines prompted contractors to hire an excessive number of unskilled craft workers to be readily available to meet project requirements. This compromise led to project managers facing the challenge of balancing between the availability and low cost of unskilled workers with eventual impacts on project 
performance. Unskilled craftworks can be cheap but they can also negatively affect project performance. The study also revealed that, despite the importance of specialized certificates, they are not usually thought of by project managers as a true measure of worker quality and experience, as they favor theoretical and hypothetical knowledge over tacit practical knowledge. Furthermore, the study provided some suggestions for government and contractors to optimize hiring craft workers for UAE construction projects.

Skilled labor shortages are one of the most challenging conundrums facing the UAE construction industry. Building and infrastructure owners and contractors could benefit by working together to come to some mutually optimal resolution. One way would be to switch from awarding contracts to the lowest bidder to awarding contracts on the basis of best value and include terms in the contracts that provide more incentives for contractors to hire skilled craft workers. Moreover, owners, policymakers, and contractors must find a way to attract and retain skilled craft workers and not lose them to other countries.

Construction companies might also find it in their long-term interest to build in greater skill acquisition training for novice employees and routine capacity development for their permanent craft workers, enabling greater production quality, greater reliability, fewer construction errors, and lower costs. This approach would ideally lead to greater employee retention, lower turnover, fewer worksite injuries, and greater organizational loyalty. Should more construction organizations take this approach, multinational workers could be more efficiently paired with staff trade experts so they can receive superior handson training as apprentices to upgrade their skillfulness and achieve greater stability for themselves as well as for construction companies.

Moreover, government and concerned private sector organizations should find a way to mutually ensure a system of providing reliable UAE craft workforce supply and demand data to enable better construction staff bidding and forecasting. They might also consider expanding funding for craft worker internships, mentoring, skills development, and welfare.

In essence, this research study has filled a gap in the research into the hiring of unskilled workers and the UAE construction industry. It has also identified the key issues regarding the availability of skilled workers and the hiring of unskilled staff within the industry to meet demands and laid down a foundation for future studies in this context. However, these initial results are indicative rather than representative, and generalizations given the sample size of experts must be rather limited. Added value is the key suggestion, having highlighted current practices, guidance, and perspectives of the industry practitioners. This research study is a stepping stone for other researchers, and future research will aim to formulate relevant frameworks and conduct quantitative assessments to address the hiring of unskilled workers in the UAE construction industry.

Author Contributions: Conceptualization and methodology, M.A. and A.S.; software and formal analysis, M.A.; data curation, M.A. and M.S.; writing—original draft preparation, M.A.; writingreview and editing, M.A., M.S. and A.S.; visualization, M.A.; supervision, M.A.; funding acquisition, M.A. and A.S. All authors have read and agreed to the published version of the manuscript.

Funding: This research received funding from the United Arab Emirates University as part of a Start-Up Research.

Informed Consent Statement: Informed consent was obtained from all subjects involved in the study.

Conflicts of Interest: The authors declare no conflict of interest.

\section{References}

1. Aschauer, D.A. Is public expenditure productive? J. Monet. Econ. 1989, 23, 177-200. [CrossRef]

2. Sgouridis, S.; Griffiths, S.; Kennedy, S.; Khalid, A.; Zurita, N. A sustainable energy transition strategy for the United Arab Emirates: Evaluation of options using an Integrated Energy Model. Energy Strateg. Rev. 2013, 2, 8-18. [CrossRef]

3. Ren, Z.; Atout, M.; Jones, J. Root Causes of Construction Project Delays in Dubai. Available online: https://docplayer.net/262216 74-Root-causes-of-construction-project-delays-in-dubai.html (accessed on 22 November 2021). 
4. Créateur, S.G.-L. The Louvre Abu Dhabi: French Universalism, Exported. JSTOR 2014, 54, 186-199. Available online: https: / / www.jstor.org/stable/26378905 (accessed on 24 November 2021).

5. Bel-Air, F. De Demography, Migration, and the Labour Market in the UAE Gulf Labour Markets and Migration. GIGA Focus 2015, 1-24. Available online: http://cadmus.eui.eu/bitstream/handle/1814/36375/GLMM_ExpNote_07_2015.pdf (accessed on 22 November 2021).

6. UAE MInistry of Economics Annual Economic Report. Available online: https://www.moec.gov.ae/documents/20121/302471 /MOE_Annual\%20Economic\%20Report_2019_.pdf/5c67375e-893f-d435-53c0-bab3cf723a36 (accessed on 23 November 2021).

7. Ali, M.; Beheiry, S. The applicability of just-in-time in United Arab Emirates Construction Projects. J. Emerg. Trends Eng. Appl. Sci. 2015, 6, 120-128. Available online: https://journals.co.za/doi/abs/10.10520/EJC171938 (accessed on 24 November 2021).

8. Mehran, D. Exploring the Adoption of BIM in the UAE Construction Industry for AEC Firms. Procedia Eng. 2016, 145, 1110-1118. [CrossRef]

9. Construction and Projects in United Arab Emirates: Overview-Global Arbitration News. Available online: https:// globalarbitrationnews.com/construction-and-projects-in-united-arab-emirates-overview/ (accessed on 24 November 2021).

10. Emirates News Agency-UAE Ministers Announce the First Set of "Projects of the 50". 2021. Available online: https://www.wam. ae/en/details/1395302966902 (accessed on 23 November 2021).

11. Ahmed, A. Expats Make up 99\% of Private Sector Staff In UAE I Uae-Gulf News. 2008. Available online: https:/ / gulfnews.com/ uae/expats-make-up-99-of-private-sector-staff-in-uae-1.96744 (accessed on 22 November 2021).

12. UAE Population Statistics 2021 (Infographics) I Dubai Population [Expat + By Country + By Nationality + Demographics] Available online: https:/ / www.globalmediainsight.com/blog/uae-population-statistics/ (accessed on 24 November 2021).

13. Ailabouni, N.; Painting, N.; Ashton, P. Factors Affecting Employee Productivity in the UAE Construction Industry. Available online: http:/ / citeseerx.ist.psu.edu/viewdoc/download?doi=10.1.1.468.5078\&rep=rep1\&type=pdf (accessed on 22 November 2021).

14. Lohiya, G. Team Building in Project Management Practice in the UAE Construction Industry. Available online: http://www. ipedr.com/vol43/007-ICFME2012-M00017.pdf (accessed on 23 November 2021).

15. 202 Nationalities in Labour Market-News I Khaleej Times. Available online: https://www.khaleejtimes.com/nation/general/202nationalities-in-labour-market (accessed on 24 November 2021).

16. Malit, F.T., Jr.; Al Youha, A. Labor Migration in the United Arab Emirates: Challenges and Responses. Available online: https://www.migrationpolicy.org/article/labor-migration-united-arab-emirates-challenges-and-responses (accessed on 22 November 2021).

17. Sami Ur Rehman, M.; Shafiq, M.T.; Afzal, M. Impact of COVID-19 on project performance in the UAE construction industry. J. Eng. Des. Technol. 2021, 20, 245-266. [CrossRef]

18. Calvetti, D.; Mêda, P.; Gonçalves, M.C.; Sousa, H. Worker 4.0: The future of sensored construction sites. Buildings 2020, 10, 169. [CrossRef]

19. Sertyesilisik, B. Embending sustainability dynamics in the lean construction supply chain management. YBL J. Built Environ. 2016, 4, 60-78. [CrossRef]

20. Daniels, R. International Standard Classification of Occupations. J. Occup. Environ. Med. 2012, 1, 615.

21. Project Management for Construction: The Owners' Perspective. Available online: https://www.cmu.edu/cee/projects/ PMbook/01_The_Owners $\backslash T 1 \backslash$ textquoteright_Perspective.html (accessed on 22 November 2021).

22. International Standard Classification of Occupations (ISCO)-ILOSTAT. Available online: https://ilostat.ilo.org/resources/ concepts-and-definitions/classification-occupation/ (accessed on 22 November 2021).

23. International Standard Classification of Education: Fields of Education and Training 2013 (ISCED-F 2013) Detailed Field Descriptions. Available online: http://uis.unesco.org/sites/default/files/documents/isced-fields-of-education-and-training2013-en.pdf (accessed on 24 November 2021).

24. Tyagi, S.; Cai, X.; Yang, K.; Chambers, T. Lean tools and methods to support efficient knowledge creation. Int. J. Inf. Manag. 2015, 35, 204-214. [CrossRef]

25. Vereen, S.C. Forecasting Skilled Labor Demand in the US Construction IndustryThe Graduate Faculty of North Carolina State University. 2013. Available online: https://www.proquest.com/openview/8bb204e97b1e918d08b7326223e94b70/1?pq-origsite= gscholar\&cbl=18750\&diss $=y$ (accessed on 23 November 2021).

26. Liu-Farrer, G.; Yeoh, B.S.; Baas, M. Social Construction of Skill: An Analytical Approach toward the Question of Skill in Cross-Border Labour Mobilities. J. Ethn. Migr. Stud. 2020, 47, 2237-2251. [CrossRef]

27. Samers, M. 'Structured Coherence': Immigration, Racism and Production in the Paris Car Industry. Eur. Plan. Stud. 2007, 6, 49-72. [CrossRef]

28. Steinberg, R.J. Social Construction of Skill: Gender, Power, and Comparable Worth. Work. Occup. 2016, 17, 449-482. [CrossRef]

29. Fitzsimmons, S.R.; Baggs, J.; Brannen, M.Y. Intersectional arithmetic: How gender, race and mother tongue combine to impact immigrants' work outcomes. J. World Bus. 2020, 55, 101013. [CrossRef]

30. Ahmed, S.; Islam, H.; Hoque, I.; Hossain, M. Reality Check against Skilled Worker Parameters and Parameters Failure Effect on the Construction Industry for Bangladesh. Int. J. Constr. Manag. 2018, 20, 480-489. Available online: https:/ / www.researchgate.net/publication/328017296_Reality_check_against_skilled_worker_parameters_and_parameters_ failure_effect_on_the_construction_industry_for_Bangladesh (accessed on 2 November 2021). [CrossRef] 
31. Yi, W.; Chan, A.P.C. Critical Review of Labor Productivity Research in Construction Journals. J. Manag. Eng. 2013, 30, 214-225. [CrossRef]

32. Ahmed, S.; Hoque, I.; Sobuz, H.R. Analysis of Skilled Worker Criteria of Construction Industry. J. Syst. Manag. Sci. 2017, 7, 53-78

33. Hamza, M.; Shahid, S.; Bin Hainin, M.R.; Nashwan, M.S. Construction labour productivity: Review of factors identified. Int. J. Constr. Manag. 2019. [CrossRef]

34. Ofori, G.; Zhang, Z.; Ling, F.Y.Y. Key barriers to increase construction productivity: The Singapore case. Int. J. Constr. Manag. 2020. [CrossRef]

35. Aljassmi, H.A.; Han, S. Classification and occurrence of defective acts in residential construction projects. J. Civ. Eng. Manag. 2014, 20, 175-185. [CrossRef]

36. Elsebaei, M.; Elnawawy, O.; Othman, A.A.E.; Badawy, M. Causes and impacts of site accidents in the Egyptian construction industry. Int. J. Constr. Manag. 2020. [CrossRef]

37. Karimi, H.; Taylor, T.R.B.; Goodrum, P.M. Analysis of the impact of craft labour availability on North American construction project productivity and schedule performance. Constr. Manag. Econ. 2017, 35, 368-380. [CrossRef]

38. Manoharan, K.; Dissanayake, P.; Pathirana, C.; Deegahawature, D.; Silva, R. Assessment of critical factors influencing the performance of labour in Sri Lankan construction industry. Int. J. Constr. Manag. 2020, 1-35. [CrossRef]

39. Karthik, D.; Kameswara Rao, C.B. Identifying the significant factors affecting the masonry labour productivity in building construction projects in India. Int. J. Constr. Manag. 2019, 1-19. [CrossRef]

40. Doloi, H. Application of AHP in improving construction productivity from a management perspective. Constr. Manag. Econ. 2008, 26, 841-854. [CrossRef]

41. Zaneldin, E.K. Construction claims in United Arab Emirates: Types, causes, and frequency. Int. J. Proj. Manag. 2006, 24, 453-459. [CrossRef]

42. Mpofu, B.; Ochieng, E.G.; Moobela, C.; Pretorius, A. Profiling causative factors leading to construction project delays in the United Arab Emirates. Eng. Constr. Arch. Manag. 2017, 24, 346-376. [CrossRef]

43. Johnson, R.M.; Babu, R.I.I. Time and cost overruns in the UAE construction industry: A critical analysis. Int. J. Constr. Manag. 2018, 20, 402-411. [CrossRef]

44. Lee, W.; Migliaccio, G.C.; Lin, K.Y.; Seto, E.Y.W. Workforce development: Understanding task-level job demands-resources, burnout, and performance in unskilled construction workers. Saf. Sci. 2020, 123, 104577. [CrossRef]

45. Healy, J.; Mavromaras, K.G.; Sloane, P.J. Adjusting to Skill Shortages: Complexity and Consequences. Soc. Sci. Res. Netw. 2011. [CrossRef]

46. Albattah, M.A.; Goodrum, P.M.; Taylor, T.R.B. New Metric of Workforce Availability among Construction Occupations and Regions. Pract. Period. Struct. Des. Constr. 2019, 24, 04019003. [CrossRef]

47. Tariq Abdelhamid, B.S.; Member, S.; Everett, J.G. Identifying Root Causes of Construction Accidents. J. Constr. Eng. Manag. 2000, 126, 52-60. [CrossRef]

48. Watson, M. Concerns for Skills Shortages in the 21st Century: A Review into the Construction Industry, Australia. Constr. Econ. Build. 2007, 7, 45-54. [CrossRef]

49. Blatter, M.; Muehlemann, S.; Schenker, S.; Wolter, S.C. Hiring costs for skilled workers and the supply of firm-provided training. Oxf. Econ. Pap. 2016, 68, 238-257. [CrossRef]

50. Stevens, M. An Investment Model for the Supply of Training by Employers. Econ. J. 1994, 104, 556-570. [CrossRef]

51. Aepli, M.; Kuhn, A. Open labor markets and Firms' substitution between training apprentices and hiring workers. Labour Econ. 2021, 70, 101979. [CrossRef]

52. Makhene, D.; Thwala, W.D. Skilled Labour Shortages In Construction Contractors: A Literature Review. Available online: https:/ / ujcontent.uj.ac.za/vital/access/services/Download/uj:5309/CONTENT1 (accessed on 24 November 2021).

53. Albattah, M.; Shan, Y.; Goodrum, P.M.; Taylor, T.R.B. Relationships between cycles of economic expansion in construction and craft workers' job satisfaction and preferences. Can. J. Civ. Eng. 2019, 44, 29-36. [CrossRef]

54. Albattah, M.; Saheed, A.; Shafiq, M.T. Employment of unskilled craft workers in the UAE construction projects: Explicating the reasons. Int. J. Innov. Technol. Explor. Eng. 2019, 8, 410-414. [CrossRef]

55. Hamid, A.; Singh, B.; Yusof, A.; Abdullah, N. The Employment of Foreign Workers at Construction Sites. In Proceedings of the 2011 2nd International Conference on Construction and Project Management, Singapore, 16-18 September 2011; Volume 15, pp. 126-130. Available online: http:/ / www.ipedr.com/vol15/25-ICCPM2011A00047.pdf (accessed on 24 November 2021).

56. Loosemore, M. A grounded theory of construction crisis management. Constr. Manag. Econ. 2010, 17, 9-19. [CrossRef]

57. Yin, R.K. Case Study Research and Applications: Design and Methods, 6th ed.; SAGE Publications Inc.: Thousand Oaks, CA, USA, 2017; p. 414.

58. Given, L.M. The SAGE Encyclopedia of Qualitative Research Methods-Google Books; SAGE Publications Inc.: Thousand Oaks, CA, USA, 2008. Available online: https://books.google.co.uk/books?hl=en\&lr=\&id=byh1AwAAQBAJ\&oi=fnd\&pg=PP1\&dq= The+Sage+encyclopedia+of+qualitative+research+methods\&ots=LPS-RL4O8s\&sig=O8nYcyZHkol_VSCkV2gBkvEDMCI\#v= onepage\&q=TheSageencyclopediaofqualitativeresearchmethods\&f=false (accessed on 24 November 2021).

59. Ridder, H.G.; Miles, M.B.; Michael Huberman, A.; Saldaña, J. Qualitative Data Analysis. A Methods Sourcebook; SAGE Publications Inc.: Thousand Oaks, CA, USA, 2018; Volume 28, pp. 485-487. [CrossRef]

60. Braun, V.; Clarke, V. Using thematic analysis in psychology. Qual. Res. Psychol. 2006, 3, 77-101. [CrossRef] 
61. Have, P. Review: David Silverman. Interpreting Qualitative Data: Methods for Analysing Talk, Text and Interaction. Forum Qual. Soz./Forum: Qual. Soc. Res. 2006, 9. [CrossRef]

62. Miles, M.B.; Huberman, M.; Saldaña, J. Qualitative Data Analysis: A Methods Sourcebook, 4th ed.; SAGE Publications Inc.: Thousand Oaks, CA, USA, 2019; p. 380.

63. Silverman, D. Interpreting Qualitative Data, 5th ed.; SAGE Publications Inc.: Thousand Oaks, CA, USA, 2015. 